(c) 2018 - ISSN 1807-2577

\title{
Analysis of maxillary sinus septa by cone-beam computed tomography
}

\author{
Análise de septos dos seios maxilares por meio de tomografia \\ computadorizada de feixe cônico \\ Camila Furtado de SOUZA ${ }^{a}$ (D), Adriano de Oliveira LOURES ${ }^{a}$ (D), \\ Daniella Guedes de Figueiredo LOPES ${ }^{a}$ (i), Karina Lopes DEVITO ${ }^{\text {a* }}$ (1) \\ a UFJF - Universidade Federal de Juiz de Fora, Faculdade de Odontologia, Juiz de Fora, MG, Brasil
}

Como citar: Souza CF, Loures AO, Lopes DGF, Devito KL. Analysis of maxillary sinus septa by cone-beam computed tomography. Rev Odontol UNESP. 2019;48:e20190034. https://dx.doi.org/10.1590/1807-2577.03419

\begin{abstract}
Resumo
Introdução: A pneumatização do seio maxilar pode impossibilitar a instalação direta de implantes na região posterior da maxila, e a solução nesses casos é submeter o paciente a uma cirurgia de levantamento do assoalho do seio maxilar. A complicação mais comum dessa cirurgia é a perfuração da membrana sinusal. Variações anatômicas no interior do seio como, por exemplo, os septos ósseos, podem dificultar ainda mais o descolamento dessa membrana. Objetivo: Avaliar a prevalência e as características dos septos sinusais em pacientes da Zona da Mata Mineira (Minas Gerais, Brasil), oferecendo informações relevantes para um planejamento mais seguro das cirurgias envolvendo essa região. Material e método: Um total de 240 seios (120 pacientes) foram analisados, por meio de imagens de tomografia computadorizada de feixe cônico (TCFC), verificando-se a presença de septos sinusais e classificando-os quanto ao tamanho e à localização anteroposterior. Resultado: Dos 120 pacientes analisados, 45 (37,50\%) apresentaram septos sinusais, sendo 66 septos no total. Destes, 33 (50\%) estavam presentes na região média do seio maxilar e o tamanho médio dos septos foi de 7,23 mm. Não existiu diferença significativa no tamanho dos septos entre os sexos ou entre os lados direito e esquerdo. Conclusão: As elevadas taxas de incidência dos septos sinusais justificam o seu estudo, que deve ser baseado principalmente em exames acurados, como a TCFC, uma vez que representam uma das variações anatômicas mais relevantes para os casos de cirurgias de levantamentos de seio.
\end{abstract}

Descritores: Radiologia; anatomia; seio maxilar; tomografia computadorizada de feixe cônico.

\begin{abstract}
Introduction: Pneumatization of the maxillary sinus may make it impossible to insert implants directly in the posterior region of the maxilla, and in these cases, the solution is to submit the patient to maxillary sinus floor augmentation surgery. The most common complication of this surgery is sinus membrane perforation. Anatomical variations of the internal space of the sinus, such as the bone septa, may further hamper detachment of this membrane. Objective: To evaluate the prevalence and characteristics of sinus septa in patients from the Zona da Mata Mineira (Minas Gerais, Brazil), to offer relevant information for a safer planning of surgeries involving this region. Material and method: A total of 120 patients (240 sinuses) were analyzed using cone-beam computed tomography (CBCT) images, verifying the presence of sinus septa and classifying them for size and anteroposterior location. Result: Of the 120 patients analyzed, $45(37.50 \%)$ had sinus septa, 66 septa in total. Of these, $33(50 \%)$ were present in the middle region of the maxillary sinus and the mean septum size was $7.23 \mathrm{~mm}$. There was no significant difference in the septum size between the genders or between the right and left sides. Conclusion: The high rates of incidence of sinus septa justify their study, which should be based mainly on accurate exams, such as CBCT, since they represent one of the most relevant anatomical variations for the cases of sinus surgeries.
\end{abstract}

Descriptors: Radiology; anatomy; maxillary sinus; cone-beam computed tomography. 


\section{INTRODUCTION}

Dental implants are increasingly used for partial and complete rehabilitation in cases of tooth losses ${ }^{1,2}$. However, the absence of maxillary molars and premolars may lead to a process of maxillary sinus pneumatization, gradually approximating it to the alveolar ridge, diminishing the bone height and frequently making it impossible to place dental implants directly in this region 3 . In these cases, a solution is to augment the floor of the maxillary sinus surgically and insert a bone graft in the area ${ }^{3,4}$.

A high percentage of maxillary sinuses have bone septa within them, with variable sizes, localizations and thicknesses, making it an even more difficult task to detach the sinus floor membrane from the bone and create space to place the graft 5,6 . Studies have demonstrated that the presence of sinus septa was a predominant risk factor for perforation of the membrane in maxillary sinus lift processes using a lateral approach ${ }^{7-9}$. The prevalence of sinus septa has shown widely divergent values in the literature, ranging between $7 \%$ and $70 \%$, according to previous studies that have used a variety of imaging exams ${ }^{10-13}$.

Due to these difficulties and obstacles in performing sinus floor augmentation surgery, professions need to have previous information for correct planning of the case ${ }^{14}$. This is obtained by means of radiographic exams that show the anatomic variations, providing the professional with the data required for surgical planning.

At present, the best choice for evaluating the maxillary sinuses would be cone beam computed tomography (CBCT) that guarantees images obtained in different planes, without superimpositions, with high quality and excellent resolution, faithfully reproducing the bone structures in addition to submitting the patient to a relatively low dose of radiation ${ }^{15-18}$.

Therefore, in this study the aim was to us CBCT images to evaluate the prevalence and characteristics of the sinus septa in patients in the Zone of the Mata Mineira area (Minas Gerais, Brazil), to make it possible to inform dentists about the anatomic variations of the maxillary sinus, thereby allowing safer and more accurate planning of surgeries involving this region.

\section{MATERIAL AND METHOD}

In this cross-sectional observational study CBCT exams were evaluated, which belonged to the files of the Dental Radiology Discipline of the Federal University of Juiz de Fora (UFJF). The research was approved by the Research Ethics Committee of UFJF (Report No. 454,857).

In total 120 exams ( 240 maxillary sinuses) were evaluated, of individuals of both genders, over the age of 18 years. For inclusion in the sample, the exams had to present a quality image covering the entire region of the maxilla. All the images were acquired by the I-Cat Next Generation ${ }^{\circledR}$ tomograph (Imaging Sciences International, Hatfield, Pennsylvania, USA), using the following acquisition protocol: rotation time of $26.9 \mathrm{~s}$, voxel size of $0.25 \mathrm{~mm}$ and FOV (field of view) of $7 \mathrm{~cm}$. The exams excluded were those of patients with craniofacial lesions or anomalies, with history of trauma and/or maxillofacial surgeries; patients who presented dental implants or bone grafts in the posterior region of the maxilla, either associated with maxillary sinus augmentation surgeries, or not.

The exams included in the study were evaluated in the I-Cat Vision software (Imaging Sciences International, Hatfield, Pennsylvania, USA) by a professional with experience with CBCT images, who verified the presence of sinus septa and classified the septa according to size and localization.

To measure the size of the maxillary sinuses, the axial cut that presented the largest antero-posterior diameter was selected for each sinus individually (Figure 1A). After selecting this cut, the measurement tool was used to measure the antero-posterior size of each sinus (Figure 1B). This measurement was divided into three equal parts, allowing the maxillary sinus to be divided into three thirds: anterior, middle and posterior (Figure 1C). This division was used to classify the localization of the sinus septa. 

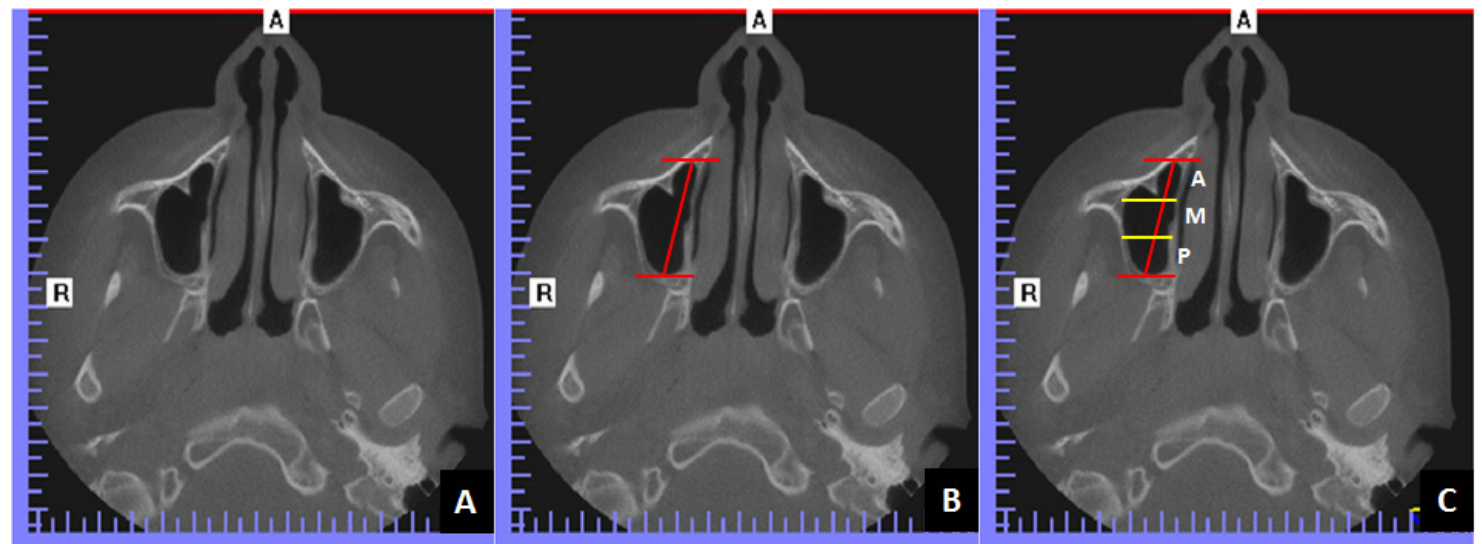

Figure 1. A. Axial cut of $C B C T$ image. B. Axial cut with larger antero-posterior diameter of the maxillary sinus. C. Axial cut illustrating division of the maxillary sinus into three thirds: anterior, middle and posterior. Letter "A" means anterior. Letter "R" means right.

All the sagittal cuts were investigated to detect the presence or absence of sinus septa. In the sagittal cuts shat showed each septum at its greatest height, the size of these septa was measured (Figure 2). In cases of maxillary sinuses with more than one septum, another sagittal cut was selected.

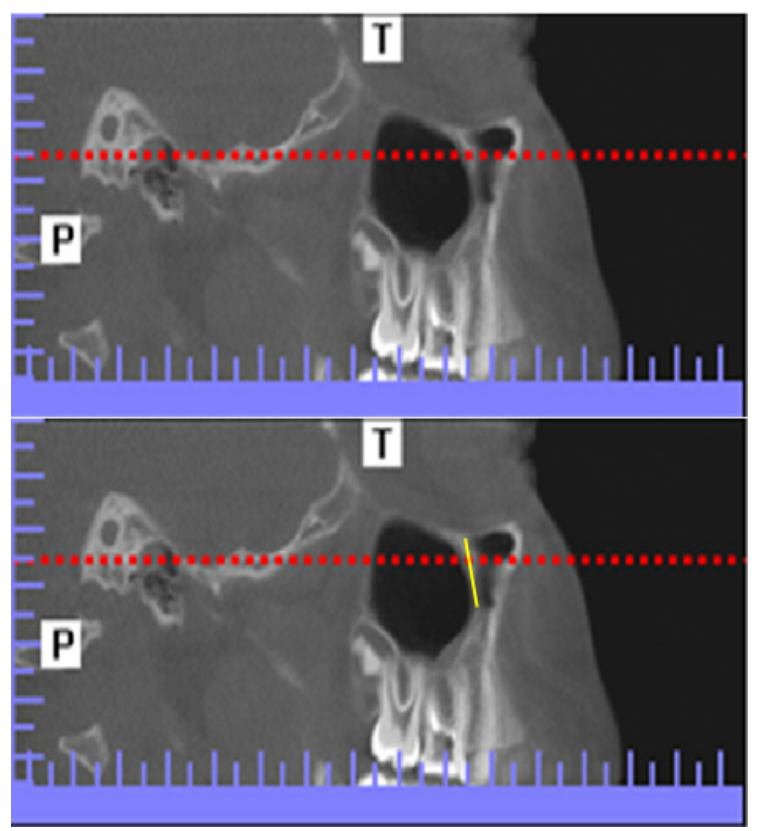

Figure 2. Sagittal cut of CBCT image in which the measurements of the sinus septa were made. Letter "T" means top. Letter "P" means posterior.

For classification of the septa in according to their antero-posterior location, the sagittal cuts selected for measuring the septa and the corresponding axial cuts were used concomitantly. With prior knowledge of the antero-posterior size of each sinus and its three thirds, the septa were classified according to their localization into anterior, middle, or posterior types.

For analysis of the results, the Kolmogorov-Smirnov test was initially applied. As the data did not present normal distribution, non-parametric tests for comparison were applied. The Wilcoxon test was used to verify the difference between the right and left sides, and the Mann-Whitney test for comparing the genders. The statistical analyses were performed in the program SPSS (Statistical Package for the Social Science, Chicago, USA), version 20.0, with a level of significance of 5\%. 


\section{RESULT}

Of the 120 patients evaluated, 71 (63.34\%) of the female, and 44 (36.67\%) of the male gender. Age ranged between 18 and 87 years.

The mean antero-posterior length of the maxillary sinus was $36.97( \pm 3.41) \mathrm{mm}$ for the female gender (ranging between $27.29 \mathrm{~mm}$ and $45.63 \mathrm{~mm}$ ) and $38.99( \pm 3.74) \mathrm{mm}$ for the male gender (ranging between $31.04 \mathrm{~mm}$ and $47.48 \mathrm{~mm}$ ). Comparison between the sides indicated no statistically significant difference $(\mathrm{p}=0.66)$, even when the sample was divided between the genders (female: $p=0.29$ / male: $p=0.12$ ). An antero-posterior length of the sinus was significantly higher for the male gender $(\mathrm{p}<0.0001)$.

Of the 120 patients evaluated, $45(37.50 \%)$ had sinus septa, and of these, $34(75.55 \%)$ had unilateral, and $11(24.44 \%)$ had bilateral septa. In total 66 sinus septa were identified as being distributed in $56(23.34 \%)$ of the 240 maxillary sinuses evaluated. Of the sinuses with septa, $48(85.71 \%)$ had only one septum, six (10.71\%) had two septa, and two (3.57\%) sinuses has three sinus septa. Relative to localization, half of the septa (33/50\%) were present in the middle region of the maxillary sinus. Table 1 shows the prevalence of the sinus septa relative to frequency and localization.

Table 1. Prevalence of the sinus septa relative to frequency and localization

\begin{tabular}{|c|c|c|c|c|c|c|c|c|c|c|c|c|}
\hline & \multirow{3}{*}{$\begin{array}{l}\text { Patiens } \\
\text { with } \\
\text { Septum }\end{array}$} & \multirow{2}{*}{\multicolumn{4}{|c|}{ Sinus with Septum }} & \multirow{3}{*}{ Septa } & \multicolumn{3}{|c|}{ Septa/Sinus } & \multicolumn{3}{|c|}{ Localization of Septa } \\
\hline & & & & & & & 1 & 2 & 3 & Anterior & Middle & Pesterior \\
\hline & & Right & Left & Bilateral & Total & & 1 & 2 & J & RMteriod & DMutuc & POStetiot \\
\hline Female & $26 / 76$ & $7 / 76$ & $11 / 76$ & $8 / 76$ & $34 / 152$ & 43 & 27 & 5 & 2 & 12 & 20 & 11 \\
\hline Male & $19 / 44$ & $11 / 44$ & $5 / 44$ & $3 / 44$ & $22 / 88$ & 23 & 21 & 1 & 0 & 6 & 13 & 4 \\
\hline Total & $45 / 120$ & $18 / 120$ & $16 / 120$ & $11 / 120$ & $56 / 240$ & 66 & 48 & 6 & 2 & 18 & 33 & 15 \\
\hline
\end{tabular}

With reference to size of the septa, no significant differences were observed between the right and left sides $(p=0.19)$ and between the genders $(p=0.40)$. The descriptive results of the sizes of sinus septa are presented in Table 2.

Table 2. Size $(\mathrm{mm})$ of the sinus septa

\begin{tabular}{|c|c|c|c|c|c|c|c|c|c|}
\hline & \multicolumn{4}{|c|}{ RIGHT SIDE } & \multicolumn{4}{|c|}{ LEFT SIDE } & \multirow{2}{*}{ TOTAI } \\
\hline & Anterior & Middle & Posterior & Total & Anterior & Middle & Posterior & Total & \\
\hline \multicolumn{10}{|c|}{ FEMALE } \\
\hline Mean & 13.01 & 5.14 & 7.29 & 8.48 & 6.38 & 6.25 & 8.10 & 6.91 & 7.69 \\
\hline SD & 6.71 & 2.32 & 4.55 & 5.30 & 5.36 & 3.76 & 6.70 & 4.79 & 5.00 \\
\hline Min. & 4.85 & 2.76 & 1.90 & 1.90 & 2.30 & 2.55 & 1.77 & 1.77 & 1.77 \\
\hline Max. & 23.23 & 8.84 & 14.50 & 23.23 & 18.09 & 13.99 & 19.13 & 19.13 & 23.23 \\
\hline \multicolumn{10}{|l|}{ MALE } \\
\hline Mean & 8.33 & 6.87 & 4.86 & 6.68 & 6.43 & 7.50 & 3.35 & 5.76 & 6.22 \\
\hline SD & 4.18 & 2.27 & 1.83 & 2.88 & 2.92 & 1.11 & 0 & 2.00 & 2.56 \\
\hline Min. & 5.77 & 3.09 & 3.50 & 3.09 & 4.37 & 5.70 & 3.35 & 3.35 & 3.09 \\
\hline Max. & 14.56 & 10.53 & 6.95 & 14.56 & 8.50 & 8.39 & 3.35 & 8.50 & 14.56 \\
\hline \multicolumn{10}{|c|}{ TOTAL } \\
\hline Mean & 10.93 & 5.95 & 6.38 & 7.75 & 6.39 & 6.45 & 7.30 & 6.71 & 7.23 \\
\hline SD & 5.93 & 2.39 & 3.79 & 4.36 & 4.75 & 3.18 & 6.29 & 4.21 & 4.27 \\
\hline Min. & 4.85 & 2.76 & 1.90 & 1.90 & 2.30 & 2.55 & 1.77 & 1.77 & 1.77 \\
\hline Max. & 23.23 & 10.53 & 14.50 & 23.23 & 18.09 & 13.99 & 19.13 & 19.13 & 23.23 \\
\hline
\end{tabular}




\section{DISCUSSION}

The alveolar bone resorption accompanying tooth losses results in a reduction in the natural bone height, thereby compromising treatment with dental implants. At present, although it is possible to use short or extra short implants ${ }^{4,19}$, alveolar ridges that do not have sufficient height must frequently be submitted to prior bone graft surgical procedures. When the area of interest is the posterior region of the maxilla, other procedures such as maxillary sinus floor augmentation procedures may be necessary. This surgery is extremely delicate as the sinus membrane may be ruptured and interfere in the physiology of the maxillary sinus. Furthermore, other anatomic characteristics, such as the presence of sinus septa may make this surgical technique even more difficult and influence the development of acute or chronic sinusitis and graft resorptions. ${ }^{7}$ In the study of Irinakis et al. ${ }^{8}$, a rate of $22.8 \%$ sinus membrane perforations occurred, irrespective of whether there was a septum interfering in the region, or not. Whereas, in sinuses in which there was interference of septa, the incidence of membrane perforation was $44.7 \%$, with large perforations occurring in $26.3 \%$ and small perforations in $18.4 \%$ of the cases.

The presence of septa in the maxillary sinus ranged between $7 \%$ and $70 \%$ according to previous studies that used very different imaging exams: panoramic radiography, conventional computed tomography and CBCT ${ }^{10-13}$. In the present study bone septa were observed in $37.5 \%$ of the patients evaluated, with $23.34 \%$ of the sinuses analyzed presenting septa. These values were among the means values of incidence found in other studies with different populations. Khalighi Sigaroudi et al. ${ }^{20}$ observed a frequency of $68.4 \%$ in 152 patients, of whom $57.9 \%$ had septa in both sinuses. Irinakis et al. ${ }^{8}$ examining pre-operative CBCT images, observed the presence of interfering septa in $48.1 \%$ of the sinuses. Şimşek Kaya et al. ${ }^{21}$ showed evidence of the presence of sinus septa in $42.1 \%$ of the 114 patients. Lang, Schulze ${ }^{9}$ found a frequency of $32 \%$ in 106 sinuses analyzed. Toraman-Alkurt et al. ${ }^{16}$ determined bilateral septa in panoramic radiographs of $5.8 \%$ of the patients, and in CBCT images of $15.4 \%$ of the patients.

In the study cited above, all the septa were considered, irrespective of their size. It is, however, important to point out that some authors determined a minimum size of sinus septum. Şimşek Kaya et al..$^{21}$ adopted septa of at least $3 \mathrm{~mm}$ for inclusion in their study. Other authors adopted $2.5 \mathrm{~mm}$ as an inclusion criterion ${ }^{9,16}$.

Another important variation among the studies was relative to the different methods for defining the localization of septa. Studies classified the septa (relative to their orientation) into: mesio-lateral (in the coronal plane); in the mesiodistal direction (antero-posterior in the sagittal plane) and horizontal position $8,10,18,21$. In the present study, the option was to use an antero-posterior classification in axial cuts. Furthermore, some authors made a direct observation in crania/cadavers 5,11 , and others evaluated the septa in imaging exams, using both panoramic radiographs $s^{9,16,22}$ and more accurate exams, emphasizing computed tomographs, either conventional ${ }^{1,7}$ or, more recently, $\mathrm{CBCT}^{12,15,18,20}$. Diverse authors pointed out that there were a high number of false-positive or false-negative diagnoses obtained from panoramic radiographs, and on the other hand, computed tomographs were better imaging exams for anatomic evaluation of the maxillary sinuses ${ }^{9,14,16,22}$.

As regards localization of the septa, higher prevalence was found in the middle region of the maxillary sinuses, as well as in the majority of studies in the literature $8,10,15,21$. In spite of the similarity of the results, showing a higher incidence of septa in the middle region of the maxillary sinus, it is worth pointing out that there is a variation in the method of classification relative to this localization, seeing that some authors used dental parameters for this purpose ${ }^{9,16,21}$. This could lead to variable results due to the size of maxillary sinuses and teeth, and it would not be applicable in edentulous individuals.

The mean size of the sinus septa found in the present study was $7.23 \mathrm{~mm}$. Neugebauer et al.23 found this size to be $11.7 \mathrm{~mm}$, while Pommer et al. ${ }^{10}$ observed a mean value of $7.5 \mathrm{~mm}$, and Talo 
Yildirim et al. ${ }^{18}$ of $4.62 \mathrm{~mm}$. Irrespective of the mean size found, the majority of studies emphasized the great variability of the sinus septum measurements, which could also be confirmed in the present study, with special attention paid to the high standard deviation patterns found.

Of the total of 56 sinuses with septa, $85.71 \%$ had only one septum, $10.71 \%$ had two, and $3.57 \%$, had three septa. Lee et al. ${ }^{1}$ observed $24.5 \%$ of sinuses with one septum, $0.39 \%$ with two, and no sinus with three septa. Lee et al. ${ }^{24}$ observed $28 \%$ of sinuses with one septum, $5 \%$ with two, and $1 \%$ sinus with three septa. Şimşek Kaya et al. ${ }^{21}$ observed only one septum in $70(93.3 \%)$ sinuses, two septa in five (6.7\%) sinuses and did not identify the presence of three or more septa. The highest incidence was of only one septum and of septa that did not divided the sinuses into two or more cavities.

In view of the high rates of incidence, studies about the prevalence of sinus septa are justified, mainly based on accurate imaging exams, such as CBCT, because they represent one of the most relevant anatomic variations to cases of maxillary sinus augmentation surgeries.

\section{CONCLUSION}

It could be concluded that approximately $37 \%$ of the patients evaluated presented sinus septa, of which the majority were unilateral. Approximately $85 \%$ of the sinuses affected presented only one single septum, with a mean size of $7.23 \mathrm{~mm}$ localized mainly in the middle region of the maxillary sinus. The high rates of incidence justified the study of sinus septa, mainly based on accurate imaging exams such as CBCT.

\section{REFERENCES}

1. Lee W-J, Lee S-J, Kim H-S. Analysis of location and prevalence of maxillary sinus septa. J Periodontal Implant Sci. 2010 Apr;40(2):56-60. http://dx.doi.org/10.5051/jpis.2010.40.2.56. PMid:20498761.

2. Esfahrood ZR, Ahmadi L, Karami E, Asghari S. Short dental implants in the posterior maxilla: a review of the literature. J Korean Assoc Oral Maxillofac Surg. 2017 Apr;43(2):70-6. http://dx.doi.org/10.5125/jkaoms.2017.43.2.70. PMid:28462189.

3. Anduze-Acher G, Brochery B, Felizardo R, Valentini P, Katsahian S, Bouchard P. Change in sinus membrane dimension following sinus floor elevation: a retrospective cohort study. Clin Oral Implants Res. 2013 Oct;24(10):1123-9. http://dx.doi.org/10.1111/j.1600-0501.2012.02520.x. PMid:22709140.

4. Thoma DS, Zeltner M, Hüsler J, Hämmerle CH, Jung RE. EAO Supplement Working Group 4 - EAO CC 2015 short implants versus sinus lifting with longer implants to restore the posterior maxilla: a systematic review. Clin Oral Implants Res. 2015 Sep;26(Suppl 11):154-69. http://dx.doi.org/10.1111/clr.12615. PMid:25997901.

5. Rosano G, Taschieri S, Gaudy JF, Lesmes D, Del Fabbro M. Maxillary sinus septa: a cadaveric study. J Oral Maxillofac Surg. 2010 Jun;68(6):1360-4. http://dx.doi.org/10.1016/j.joms.2009.07.069. PMid:20231050.

6. Marin S, Kirnbauer B, Rugani P, Payer M, Jakse N. Potential risk factors for maxillary sinus membrane perforation and treatment outcome analysis. Clin Implant Dent Relat Res. 2019 Feb;21(1):66-72. http://dx.doi.org/10.1111/cid.12699. PMid:30475442.

7. Schwarz L, Schiebel V, Hof M, Ulm C, Watzek G, Pommer B. Risk factors of membrane perforation and postoperative complications in sinus floor elevation surgery: review of 407 augmentation procedures. J Oral Maxillofac Surg. 2015 Jul;73(7):1275-82. http://dx.doi.org/10.1016/j.joms.2015.01.039. PMid:25921824. 
8. Irinakis T, Dabuleanu V, Aldahlawi S. Complications during maxillary sinus augmentation associated with interfering septa: a new classification of septa. Open Dent J. 2017 Mar 22;11:140-150. http://dx.doi.org/10.2174/1874210601711010140.

9. Lang AC, Schulze RK. Detection accuracy of maxillary sinus floor septa in panoramic radiographs using CBCT as gold standard: a multi-observer receiver operating characteristic (ROC) study. Clin Oral Investig. 2019 Jan;23(1):99-105. http://dx.doi.org/10.1007/s00784-018-2414-1. PMid:29525926.

10. Pommer B, Ulm C, Lorenzoni M, Palmer R, Watzek G, Zechner W. Prevalence, location and morphology of maxillary sinus septa: systematic review and meta-analysis. J Clin Periodontol. 2012 Aug;39(8):76973. http://dx.doi.org/10.1111/j.1600-051X.2012.01897.x. PMid:22624862.

11. Gandhi KR, Wabale RN, Siddiqui AU, Farooqui MS. The incidence and morphology of maxillary sinus septa in dentate and edentulous maxillae: a cadaveric study with a brief review of the literature. J Korean Assoc Oral Maxillofac Surg. 2015 Feb;41(1):30-6. http://dx.doi.org/10.5125/jkaoms.2015.41.1.30. PMid:25741466.

12. Sakhdari S, Panjnoush M, Eyvazlou A, Niktash A. Determination of the prevalence, height, and location of the maxillary sinus septa using cone beam computed tomography. Implant Dent. 2016 Jun;25(3):335-40. http://dx.doi.org/10.1097/ID.0000000000000380. PMid:26866846.

13. Zhang YQ, Yan XB, Meng Y, Zhao YN, Liu DG. Morphologic analysis of maxillary sinus floor and its correlation to molar roots using cone beam computed tomography. Chin J Dent Res. 2019;22(1):29-36. http://dx.doi.org/10.3290/j.cjdr.a41772. PMid:30746530.

14. Beretta $\mathrm{M}$, Cicciù $\mathrm{M}$, Bramanti E, Maiorana C. Schneider membrane elevation in presence of sinus septa: anatomic features and surgical management. Int J Dent. 2012;2012:261905. http://dx.doi.org/10.1155/2012/261905. PMid:22848223.

15. Orhan K, Kusakci Seker B, Aksoy S, Bayindir H, Berberoğlu A, Seker E. Cone Beam CT evaluation of maxillary sinus septa prevalence, height, location and morphology in children and an adult population. Med Princ Pract. 2013;22(1):47-53. http://dx.doi.org/10.1159/000339849. PMid:22832185.

16. Toraman-Alkurt M, Peker I, Değerli S, Cebeci ARI, Sadik E. Comparison of cone-beam computed tomography and panoramic radiographs in detecting maxillary sinus septa. J Istanb Univ Fac Dent. 2016 Oct 1;50(3):8-14. http://dx.doi.org/10.17096/jiufd.84476.

17. Lozano-Carrascal N, Salomó-Coll O, Gehrke SA, Calvo-Guirado JL, Hernández-Alfaro F, Gargallo-Albiol J. Radiological evaluation of maxillary sinus anatomy: A cross-sectional study of 300 patients. Ann Anat. 2017 Nov;214:1-8. http://dx.doi.org/10.1016/j.aanat.2017.06.002. PMid:28759740.

18. Talo Yildirim T, Güncü GN, Colak M, Nares S, Tözüm TF. Evaluation of maxillary sinus septa: a retrospective clinical study with cone beam computerized tomography (CBCT). Eur Rev Med Pharmacol Sci. 2017 Dec;21(23):5306-14. http://dx.doi.org/10.26355/eurrev_201712_13912. PMid:29243773.

19. Ravidà A, Barootchi S, Askar H, Suárez-López Del Amo F, Tavelli L, Wang HL. Long-term effectivess of extra-short ( $\leq 6 \mathrm{~mm}$ ) dental implants: a systematic review. Int J Oral Maxillofac Implants. 2019 Jan/Feb;34(1):68-84. http://dx.doi.org/10.11607/jomi.6893. PMid:30695086.

20. Khalighi Sigaroudi A, Dalili Kajan Z, Rastgar S, Neshandar Asli H. Frequency of different maxillary sinus septal patterns found on cone-beam computed tomography and predicting the associated risk of sinus membrane perforation during sinus lifting. Imaging Sci Dent. 2017 Dec;47(4):261-7. http://dx.doi.org/10.5624/isd.2017.47.4.261. PMid:29279826.

21. Şimşek Kaya G, Daltaban Ö, Kaya M, Kocabalkan B, Sindel A, Akdağ M. The potential clinical relevance of anatomical structures and variations of the maxillary sinus for planned sinus floor elevation procedures: a retrospective cone beam computed tomography study. Clin Implant Dent Relat Res. 2019 Feb;21(1):114-21. http://dx.doi.org/10.1111/cid.12703. PMid:30556642.

22. Maestre-Ferrín L, Carrillo-García C, Galán-Gil S, Peñarrocha-Diago M, Peñarrocha-Diago M. Prevalence, location, and size of maxillary sinus septa: panoramic radiograph versus computed tomography scan. J 
Oral Maxillofac Surg. 2011 Feb;69(2):507-11. http://dx.doi.org/10.1016/j.joms.2010.10.033. PMid:21238847.

23. Neugebauer J, Ritter L, Mischkowski RA, Dreiseidler T, Scherer P, Ketterle M, et al. Evaluation of maxillary sinus anatomy by cone-beam CT prior to sinus floor elevation. Int J Oral Maxillofac Implants. 2010 Mar-Apr;25(2):258-65. PMid:20369083.

24. Lee HW, Lin WS, Morton D. A retrospective study of complications associated with 100 consecutive maxillary sinus augmentations via the lateral window approach. Int J Oral Maxillofac Implants. 2013 May-Jun;28(3):860-8. http://dx.doi.org/10.11607/jomi.2793. PMid:23748320.

\section{CONFLICTS OF INTERESTS}

The authors declare no conflicts of interest.

\section{*CORRESPONDING AUTHOR}

Karina Lopes Devito, UFJF - Universidade Federal de Juiz de Fora, Faculdade de Odontologia, Departamento de Clínica Odontológica, Campus Universitário, s/n, 36036-900 Juiz de Fora - MG, Brasil, e-mail: karina.devito@ufjf.edu.br

Received: March 25, 2019

Accepted: May 6, 2019 